\title{
Inflow Behavior Observation of Molten Mold Powder between Mold and Solidified Shell by Continuous Casting Simulator Using $\mathrm{Sn}-\mathrm{Pb}$ Alloy and Stearic Acid
}

\author{
Koichi TSUTSUMI, Jun-ichi OHTAKE") and Mitsutaka HINO2) \\ Formerly Graduate School of Engineering, Tohoku University. Now at Materials \& Processing Research Center, NKK \\ Corporation, 1 Kokan-cho, Fukuyama, Hiroshima-Prf., 721-8510 Japan. 1) Formerly Student of Graduate School of \\ Engineering, Tohoku University. Now at Kure Works, Nisshin Steel Co. Ltd., Showa-cho, Kure, Hiroshima-Prf., 737-8520 \\ Japan. $\quad 2$ 2) Graduate School of Engineering, Tohoku University, Aoba-yama 02, Sendai, 980-8579 Japan.
}

(Recieved on November 30, 1999; accepted in final form on February 9, 2000)

\begin{abstract}
High productivity and high quality slab machine have been recently required in continuous casting process to lower the cost of steel production. It is important to know the inflow behavior of mold powder between mold and solidified shell to develop higher-speed casting. The purpose in this study is to make clear the mechanism of lubrication between mold and solidified shell. Sn-5mass\%Pb alloy and stearic acid were used as substituted of liquid steel and molten mold powder in the experiment simulated continuous casting machine. Direct observation on inflow behavior of mold powder was made experimentally by a digital video camera. The friction force between mold and solidified shell was measured by a load cell which was set under the mold. Mold powder flowed into the aperture between mold and solidified shell during both positive strip time period and negative strip time period and the amount of powder consumption in positive strip time period was more than that in negative strip time period. The friction force between mold and solidified shell decreased when positive strip time ratio increased. When the modification rate or amplitude increased, or when frequency or casting speed decreased, the friction force decreased. These inclinations corresponded with those in the industrial continuous casting machine qualitatively.
\end{abstract}

KEY WORDS: continuous casting; mold powder; lubrication; oscillation; positive strip time; negative strip time; friction force.

\section{Introduction}

High productivity and high quality slab machine have been recently required in continuous casting process to lower the cost of steel production. It is important to know the inflow behavior of mold powder between mold and solidified shell to develop higher-speed casting. But there have been two opposite opinions about the period of inflow of mold powder. One is the positive strip time $\left(t_{\mathrm{p}}\right)$ period, the other is negative strip time $\left(t_{\mathrm{n}}\right)$ period.

Kitagawa et $a l .{ }^{1)}$ pointed out that powder consumption rate was proportional to $t_{\mathrm{p}}$ in a laboratory scale experiment, and they confirmed that this inclination could be applied to the continuous casting machine in steel plant. After that, Mizukami et $a l .{ }^{2)}$ and Suzuki et al. ${ }^{3)}$ researched various oscillation waves and developed non-sinusoidal (non-sin.) oscillation from sinusoidal (sin.) oscillation. Non-sin. oscillation increased $t_{\mathrm{p}}$ and improved the lubrication between mold and solidified shell. As the result, non-sin. oscillation has made the casting speed increase furthermore by 0.5 $\mathrm{m} / \mathrm{min}$ in comparison with sin. oscillation ${ }^{3)}$. And it has achieved high productivity in a continuous casting process.

On the other hand, there are opposite opinions that the period of inflow of mold powder period is $t_{\mathrm{n}}$ period. Emi et $a l .{ }^{4)}$ reported that the slag rim around meniscus made molten mold powder flow into the aperture between mold and solidified shell in $t_{\mathrm{n}}$ period. Anzai et al. ${ }^{5)}$ calculated the inflow behavior of mold powder using the Navier-Stokes equation. It was assumed in their paper that the flow of mold powder between mold and solidified shell was the flow between quasi parallel plates. As the result, they concluded that molten mold powder flowed into the aperture in $t_{\mathrm{n}}$ period.

In the present study, the purpose is to make clear the mechanism of lubrication behavior between mold and solidified shell. The experimental apparatus simulated a continuous casting machine, ${ }^{6}$ and $\mathrm{Sn}-5 \mathrm{mass} \% \mathrm{~Pb}$ alloy and stearic acid were used in this experiment as substituted of liquid steel and molten mold powder. Direct observation on inflow behavior of mold powder was made experimentally by a digital video camera and various data concerning friction force and so on were obtained at the same time.

There had been a few reports about direct observation around meniscus. Matsushita et $a l^{7)}$ observed the shape and fluctuation of the meniscus directly through the quartz glass which was set on the part of water-cooled copper in contin- 


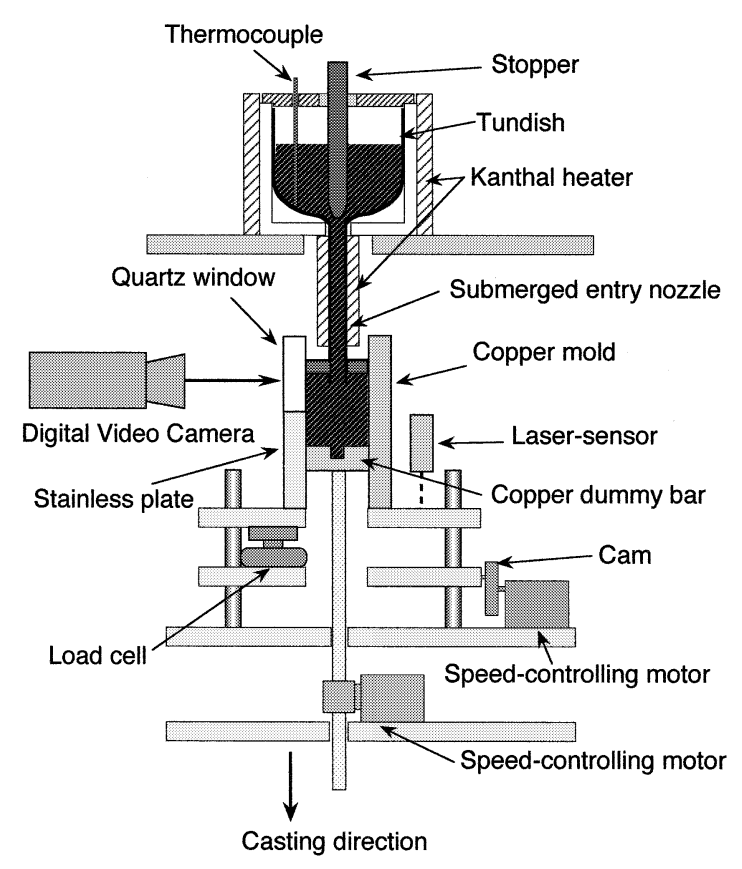

Fig. 1. Schematic diagram of experimental apparatus.

uous casting machine in steel plant. Tada et $a l .{ }^{8)}$ and Kudoh et al. . $^{9}$ observed the formation of the oscillation mark using the alloy which had low melting point, and dummy powder in a laboratory scale experiment.

Similarly there have been a few reports ${ }^{10)}$ about the direct observation of the inflow of mold powder between mold and solidified shell. Therefore, the mechanism of lubrication behavior between mold and solidified shell is discussed in this paper based on the direct observation and measurement of friction force.

\section{Experiments}

Figure 1 shows the schematic diagram of experimental apparatus simulating continuous casting machine. Sn5 mass $\% \mathrm{~Pb}$ and stearic acid were selected as substituted of liquid steel and molten mold powder because of their low melting points for a suitable experiment to simulate continuous casting machine. Fine $\mathrm{Al}_{2} \mathrm{O}_{3}$ powder about $0.3 \mathrm{~mm}$ in diameter was gradually added in liquid stearic acid as a tracer during casting to observe the inflow behavior of mold powder. The mold size was $50 \mathrm{~mm}$ square of cross section and $180 \mathrm{~mm}$ in length. The mold was made of three watercooled copper blocks and an observation quartz window. Generally speaking, the mold taper was about $10 \mathrm{~mm} / \mathrm{m}$ in a continuous casting machine, that was, the area in the exit of the mold was narrower than that in the inlet of the mold. But the mold taper was not given and set vertically in this experimental apparatus to simplify the inflow phenomenon. The instruments for oscillating the mold were composed of a cam and its rotary speed controlling motor electrically, where various oscillating modes were able to be altered by exchanging the cam.

Metal was melted in a furnace which served as a tundish. Metal weight was about $3.4 \mathrm{~kg}$, so the length of strand became about $180 \mathrm{~mm}$ because mold size was $50 \mathrm{~mm}$ square of cross section. Casting time was about $60 \mathrm{~s}$ and $90 \mathrm{~s}$. Molten metal was poured through a submerged entry noz-
Table 1. Experimental conditions.

\begin{tabular}{|c|c|c|}
\hline Material & Metal & Sn-5mass $\% \mathrm{~Pb}\left(\mathrm{~T}_{\mathrm{m}}=495 \mathrm{~K}\right)$ \\
\cline { 2 - 3 } & Quasi-powder & Stearic acid $\left(\mathrm{T}_{\mathrm{m}}=343 \mathrm{~K}\right)$ \\
\cline { 2 - 3 } & Tracer & Fine $\mathrm{Al}_{2} \mathrm{O}_{3}$ powder \\
\hline Oscillation & Mode & Sin., Non-Sin. $(\alpha=40 \%)$ \\
\cline { 2 - 3 } & Amplitude, $\mathrm{A}$ & $\pm 3, \pm 7[\mathrm{~mm}]$ \\
\cline { 2 - 3 } & Frequency, $\mathrm{f}$ & $0.5,1[\mathrm{~Hz}]$ \\
\cline { 2 - 3 } & Casting speed, $\mathrm{Vc}$ & $2.0,3.0[\mathrm{~mm} / \mathrm{s}]$ \\
\hline Super heat & Metal & $50[\mathrm{~K}]$ \\
\cline { 2 - 3 } & Quasi-powder & $10[\mathrm{~K}]$ \\
\hline \multirow{3}{*}{ Weight } & Metal & $3.4[\mathrm{~kg}]$ \\
\cline { 2 - 3 } & Quasi-powder & $50[\mathrm{~g}]$ \\
\cline { 2 - 3 } & Tracer & $2-3[\mathrm{~g}]$ \\
\hline
\end{tabular}

Table 2. Correspondence between marks and casting conditions.

\begin{tabular}{|c|r|r|r|r|r|r|r|r|r|r|r|r|r|r|r|r|}
\hline mark & $\bigcirc$ & $\boldsymbol{O}$ & $\triangle$ & $\boldsymbol{\Delta}$ & $\mathbf{D}$ & $\mathbf{0}$ & $\boldsymbol{\Delta}$ & $\boldsymbol{\Delta}$ & $\square$ & $\boldsymbol{\nabla}$ & $\nabla$ & $\boldsymbol{\nabla}$ & $\mathbf{\nabla}$ & $\mathbf{0}$ & $\mathbf{\nabla}$ & $\mathbf{\nabla}$ \\
\hline$\alpha(\%)$ & 0 & 0 & 0 & 0 & 0 & 0 & 0 & 0 & 40 & 40 & 40 & 40 & 40 & 40 & 40 & 40 \\
\hline $\mathrm{Vc}(\mathrm{mm} / \mathrm{s})$ & 2 & 2 & 2 & 2 & 3 & 3 & 3 & 3 & 2 & 2 & 2 & 2 & 3 & 3 & 3 & 3 \\
\hline $\mathrm{f}(1 / \mathrm{s})$ & 0.5 & 1.0 & 0.5 & 1.0 & 0.5 & 1.0 & 0.5 & 1.0 & 0.5 & 1.0 & 0.5 & 1.0 & 0.5 & 1.0 & 0.5 & 1.0 \\
\hline $\mathrm{A}(\mathrm{mm})$ & 3 & 3 & 7 & 7 & 3 & 3 & 7 & 7 & 3 & 3 & 7 & 7 & 3 & 3 & 7 & 7 \\
\hline
\end{tabular}

zle. The flow rate of molten metal was controlled by a stopper to stabilize the position of the interface between metal and molten mold powder (meniscus). The straight type submerged entry nozzle was used and was soaked at $10 \mathrm{~mm}$ depth from the meniscus. The tundish and submerged entry nozzle were made of pyrex glass. A dummy bar for withdrawing a strand was withdrawn downwards at a constant speed by another motor. The inflow behavior of mold powder and initial solidified shell around meniscus were recorded through a quartz window every $1 / 30 \mathrm{~s}$ by a digital video camera. The quartz glass set in the meniscus was pre-heated at $423 \mathrm{~K}$ in the furnace to reduce the solidified deposit as an obstacle for the observation. The mold displacement was monitored by a CCD laser sensor and the change of load on the mold was measured by a load cell which was set under the mold to measure the friction force between mold and solidified shell. These data were accumulated in personal computer after analog records were converted to digital records through a data logger every $25 \mathrm{~ms}$. Several minutes later after the experiment, the mold was taken apart to pieces to collect solidified mold powder, which flowed into the aperture between mold and solidified shell and contacted the mold, and 20 pieces of them were selected at random, and then the thickness of their film was measured by a microgage and the amount of powder consumption was estimated. It was difficult to measure the correct thickness of the part of oscillation mark by a microgage because solid stearic acid was soft. So the thickness of their film was measured in the part which was not correspond to oscillation mark.

Table 1 shows the experimental conditions. The experiments were carried out on the 16 kinds of casting conditions. Normally casting conditions were selected on the condition that negative strip time ratio was constant, but these casting conditions in Tables 1 and $\mathbf{2}$ had to be selected because it was difficult to carry out the stable experiment using small experimental apparatus. And these casting conditions could be got the effect of the individual parameters of casting conditions. Mold oscillation were adopted the $\sin$. wave and non-sin. wave. The modification rate of non- 

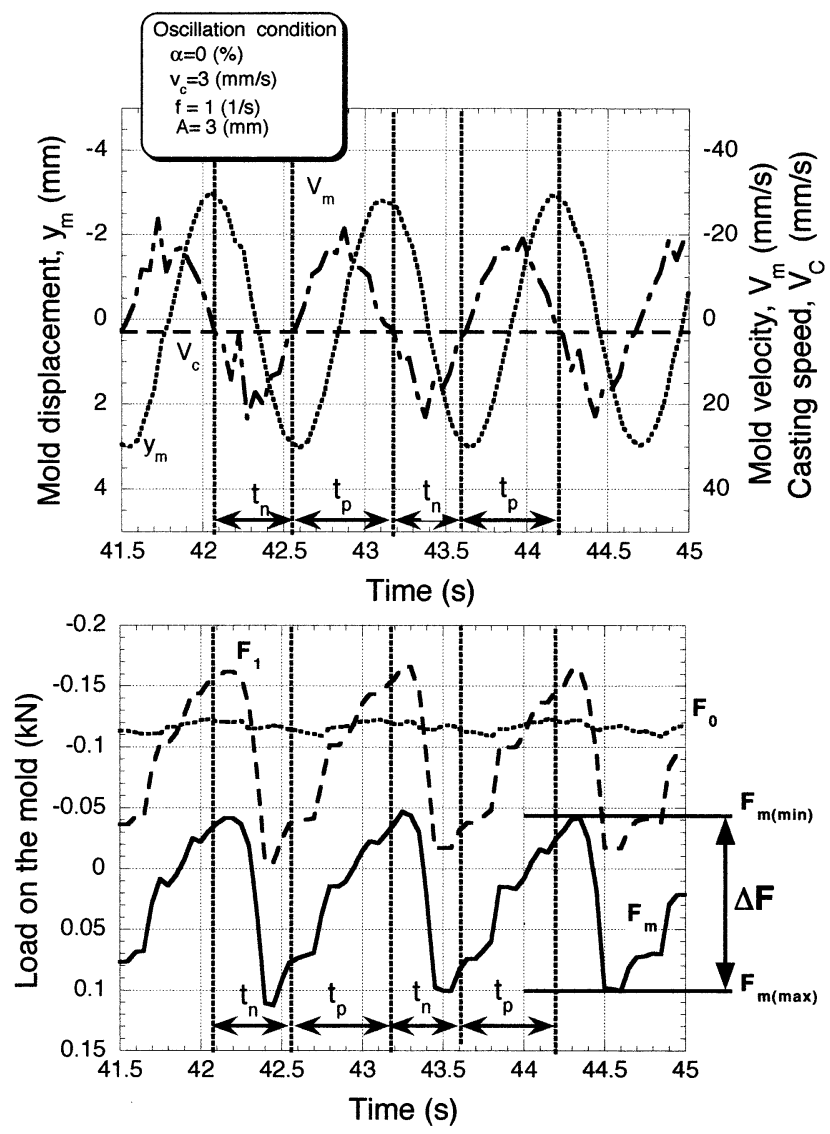

Fig. 2. Relation among time, load on the mold displacement, mold velocity and casting speed.

sin. wave was adopted the $40 \%$ based on the experiment after Suzuki et al. ${ }^{3)}$ because the larger modification rate of non-sin. wave got the distinct results between sin. and nonsin. waves. Table 2 shows the correspondence between marks and casting conditions in the following figures. The values of casting speed, mold and tracer displacement, and so on were assumed that positive values were in the gravity direction.

\section{Results}

\subsection{Measurement of Friction Force between Mold and Solidified Shell}

It is recognized that friction force relates with lubrication closely and is influenced by the casting conditions. The change of load on the mold was measured by a load cell to estimate the friction force between mold and solidified shell. The load on the mold, $F_{\mathrm{m}}$, was calculated by

$$
F_{\mathrm{m}}=F_{1}-F_{0},
$$

where $F_{1}$ indicated the load with casting, and $F_{0}$ indicated the load without casting which was measured before casting. When the load on the mold, $F_{\mathrm{m}}$, was calculated using Eq. (1), the displacement of the mold were made to be corresponded between that with casting and without casting. Figure 2 shows one example of the load change measurement. The positive value of the load cell means that the downward force works on the mold in the gravity direction, in other words, upward force works on the solidified shell. The value on $x$-axis in Fig. 2 indicates the stable period on those casting conditions after the tip of strand appears from the exit of the mold, and that on $y$-axis in lower of Fig. 2 indicates the change of the load on the mold. The load on the mold increased when the period in mold oscillation was $t_{\mathrm{p}}$ period $\left(V_{\mathrm{m}}-V_{\mathrm{C}}>0\right)$, and that decreased when the period in mold oscillation was $t_{\mathrm{n}}$ period $\left(V_{\mathrm{m}}-V_{\mathrm{C}}<0\right)$. As the result, the direction of the load on the mold changed and the load on the mold increased rapidly when time changed from $t_{\mathrm{n}}$ to $t_{\mathrm{p}}$ period. These inclinations corresponded with the results measured the friction force between mold and solidified shell in continuous casting machine in industrial steel plant by Mizukami et l. $^{2)}$ Therefore, it was induced that the load on the mold between mold and solidified shell in the experimental apparatus could simulate the friction force between mold and solidified shell in the continuous casting machine of steel plant. Then friction force between mold and solidified shell per unit of contacted area, $\Delta F / S$, is defined as follows in this paper.

$$
\frac{\Delta F}{S}=\frac{F_{\mathrm{m}(\max )}-F_{\mathrm{m}(\min )}}{S}
$$

$F_{\mathrm{m}(\max )}$ indicates the maximum load on the mold in one period of the mold oscillation, $F_{\mathrm{m} \text { (min) }}$ indicates the minimum load on the mold in one period of the mold oscillation, and $S$ indicates the contact area between mold and strand except for quartz glass and stainless plate which was set under the quartz glass and was not cooled by water. It is recognized that negative strip time ratio (NSR) is one of effective and famous parameters to be characteristics of the casting conditions. In this paper NSR and positive strip time ratio (PSR) are defined as follows,

$$
\begin{aligned}
& \mathrm{NSR}=\frac{t_{\mathrm{n}}}{t_{p}+t_{n}} \times 100(\%) \\
& \mathrm{PSR}=\frac{t_{\mathrm{p}}}{t_{\mathrm{p}}+t_{\mathrm{n}}} \times 100(\%)
\end{aligned}
$$

Therefore, it was tried to arrange the casting conditions with PSR in this paper. Figure 3 shows the relation between PSR and friction force between mold and solidified shell. The correspondence between marks and casting conditions is shown in Table 2. It had effects on the decrease of friction force between mold and solidified shell to decrease the casting speed or the frequency of mold oscillation and to increase the amplitude, that meant increase of PSR. The friction force in non-sin. oscillation was smaller than that in sin. oscillation. In non-sin. oscillation, $t_{\mathrm{p}}$ could be longer, that was, PSR could be bigger than that in sin. oscillation. These inclinations corresponded qualitatively with the experience of the continuous casting operation in the industrial steel plants. ${ }^{11)}$

\subsection{Effect of Measured Thickness of Mold Powder Film on the Lubrication between Mold and Solidified Shell}

It was recognized that powder consumption affected largely the lubrication between mold and solidified shell. Therefore, the relation between the lubrication measurement results and powder consumption had been discussed. ${ }^{12)}$ Generally speaking, the relation between powder 


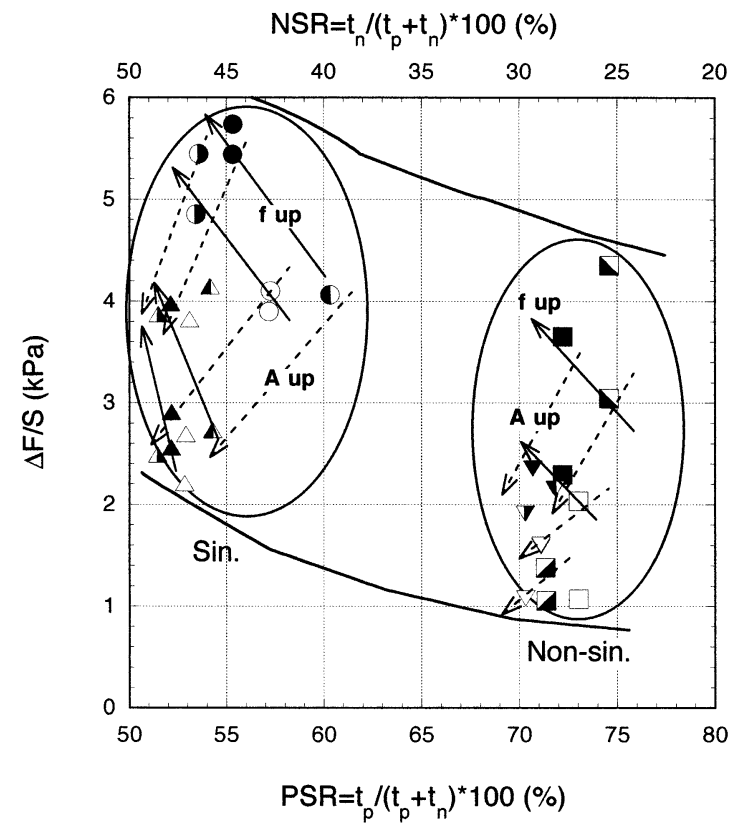

Fig. 3. Relation among postive strip time ratio, PSR, negative strip time ratio, NSR, and friction force, $\Delta F / S$. (The correspondence between marks and casting conditions is shown in Table 2.)

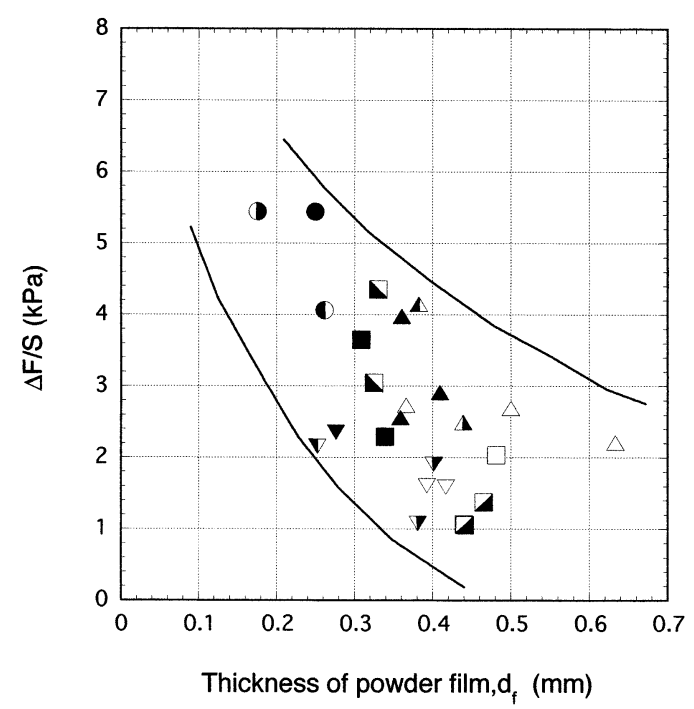

Fig. 4. Relation between thickness of powder film, $d_{\mathrm{f}}$, and friction force, $\Delta F / S$. (The correspondence between marks and casting conditions is shown in Table 2.)

consumption, $Q$, and thickness of powder film, $d_{\mathrm{f}}$, can be expressed from the definition of powder consumption as follows,

$$
Q=\frac{\rho d_{\mathrm{f}} S}{S}=\rho d_{\mathrm{f}}
$$

where $\rho$ indicates the density of molten mold powder. Figure 4 shows the relation between measured thickness of powder film and friction force between mold and solidified shell in the present work. The thicker the thickness of powder film was, the smaller the friction force was. It was, therefore, concluded that the casting conditions on which the thickness of powder film became thick improved the lubrication, so that, the friction force decreased. These results

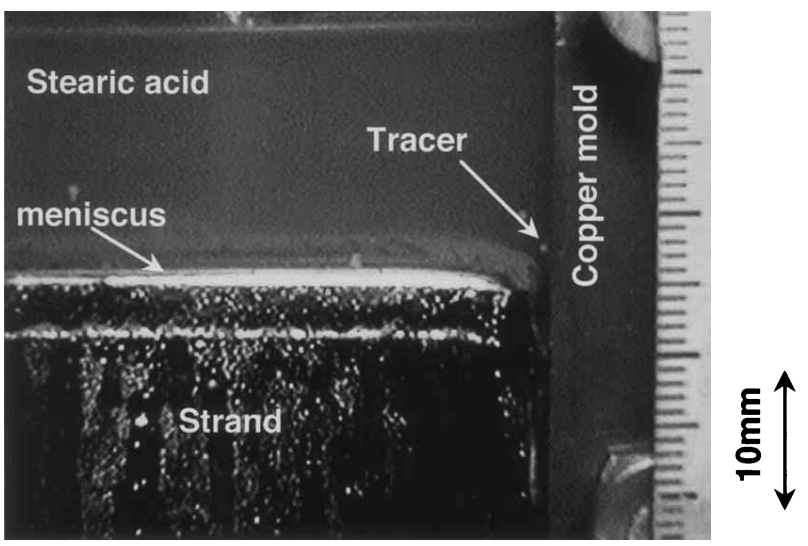

Fig. 5. An example photographs around meniscus through the observation window.

were corresponded with the experience of industrial continuous casting machine, ${ }^{3,13)}$ so that this experimental equipment might simulate the lubricant behavior of mold powder of industrial continuous casting process.

\subsection{Inflow Behavior of Fine $\mathrm{Al}_{2} \mathrm{O}_{3}$ Tracer in Stearic Acid between Mold and Solidified Shell}

Figure 5 shows an example of photograph around the meniscus taken by digital video camera. The drift of meniscus level was stable as shown in this photograph, and the slag rim $^{4)}$ was reported to be formed around meniscus in industrial continuous casting of steel plant, but it was not observed in this simulation experiment using $\mathrm{Sn}-\mathrm{Pb}$ alloy and stearic acid. So the mechanism of inflow behavior of mold powder and the movement of initial solidified shell will be discussed on the condition that there is no slag rim around meniscus in this paper. Some white points in stearic acid layer in this photograph were fine $\mathrm{Al}_{2} \mathrm{O}_{3}$ tracer as a mark for inflow behavior observation of stearic acid, but some white circle in the strand was not tracer but pinhole by air. The white line which was located $7 \mathrm{~mm}$ under the meniscus was not meniscus but scum which was occurred in the short of pre-heating of quartz glass. Figure 6 shows the continuous photographs about the movement of tracer around meniscus near the mold. The tracer which was indicated at the tip of white arrow was followed and the displacement of this tracer was measured every $25 \mathrm{~ms}$ against a scale which was fixed on the ground. Figure 7 shows the observation result of inflow behavior of fine $\mathrm{Al}_{2} \mathrm{O}_{3}$ tracer around meniscus versus time. The mold displacement, $y_{\mathrm{m}}$, mold velocity, $V_{\mathrm{m}}$ and casting speed, $V_{\mathrm{C}}$, were also plotted in this figure simultaneously. The period which increased rapidly inflow velocity of fine $\mathrm{Al}_{2} \mathrm{O}_{3}$ tracer was the middle period while the mold oscillated upwards (time $=2.2-2.4 \mathrm{~s}$ in Fig. 7), that was, it was the period that mold velocity became the maximum. This period which increased rapidly inflow velocity corresponded to $t_{\mathrm{p}}$ period. In regard to other casting conditions, the period which increased rapidly inflow velocity of fine $\mathrm{Al}_{2} \mathrm{O}_{3}$ tracer was the same period nearly. The maximum scattering about the period was $0.2 \mathrm{~s}$. And then the difference of casting conditions could not be made clear in our experimental apparatus using $\mathrm{Sn}-\mathrm{Pb}$ alloy and stearic acid. Elucidation of this relation among casting conditions is one of future research subjects. And our experimental equipment must be improved for direct observation about 


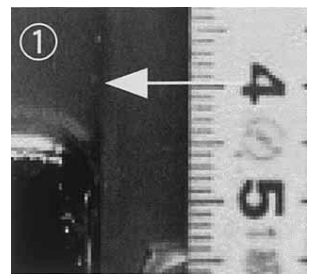

$\mathrm{t}=1.3 \mathrm{~s}$ in Fig.7

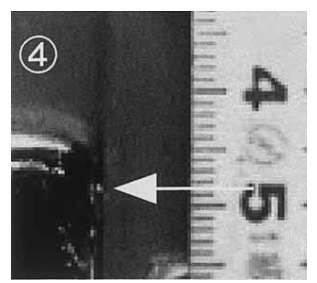

$\mathrm{t}=2.4 \mathrm{~s}$ in Fig. 7

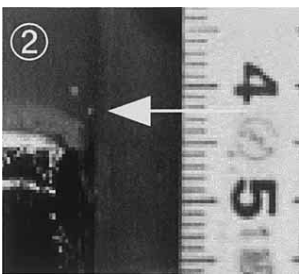

$t=1.7 \mathrm{~s}$ in Fig.7

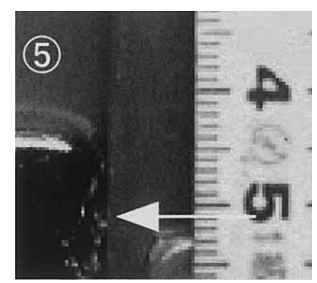

$\mathrm{t}=2.7 \mathrm{~s}$ in Fig. 7

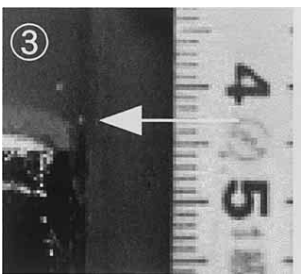

$\mathrm{t}=2.1 \mathrm{~s}$ in Fig.7

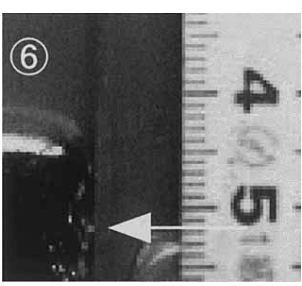

$\mathrm{t}=3.1 \mathrm{~s}$ in Fig.7

Fig. 6. Continuous photographs about the movement of tracer around meniscus near the mold. (Oscillation conditions: Sin.wave, $V_{\mathrm{C}}=2 \mathrm{~mm} / \mathrm{s}, f=0.5 \mathrm{~Hz}, A=3 \mathrm{~mm}$.)
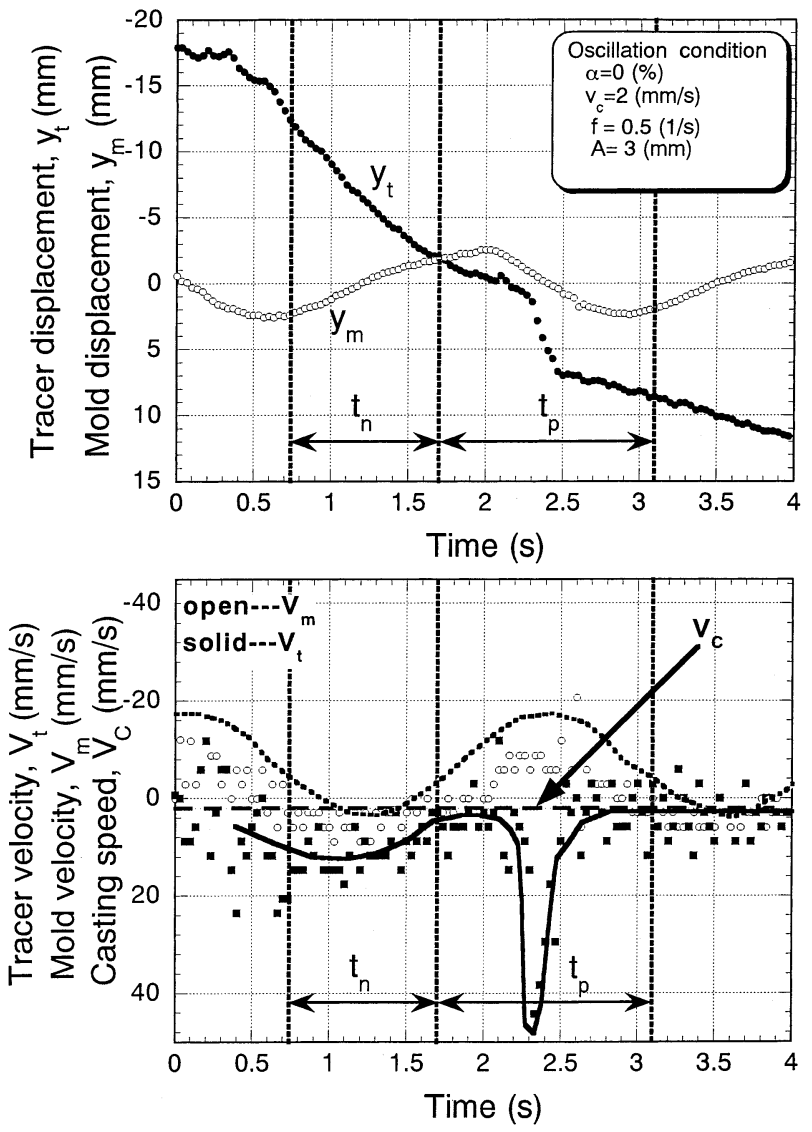

Fig. 7. Inflow behavior of $\mathrm{Al}_{2} \mathrm{O}_{3}$ tracer around meniscus near the mold. (Oscillation conditions: Sin. wave, $V_{\mathrm{C}}=2 \mathrm{~mm} / \mathrm{s}$, $f=0.5 \mathrm{~Hz}, A=3 \mathrm{~mm}$.)

inflow of mold powder.

\subsection{Behavior of Initial Solidified Shell}

The behavior of initial solidified shell around meniscus was observed through the observation window. Normally there have been 2 kinds of opinions about the formation of
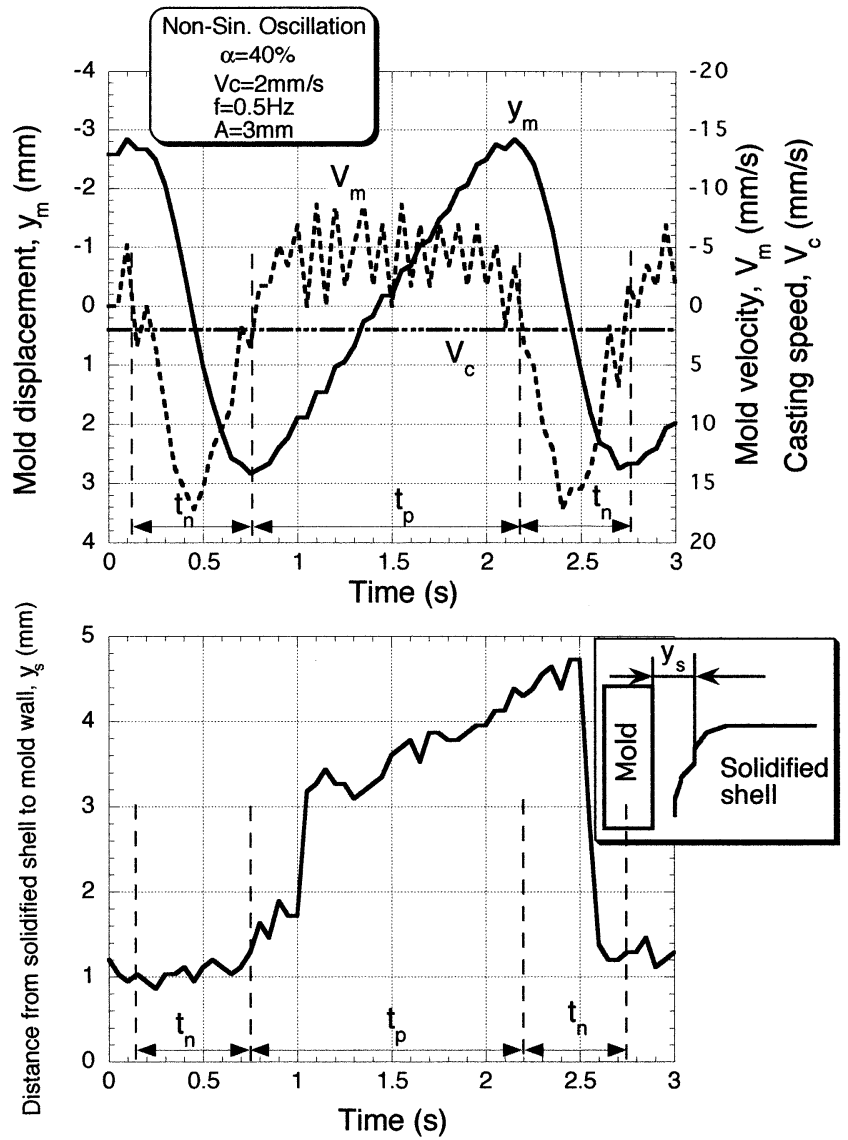

Fig. 8. Direct observation of the formation of oscillation mark. (Oscillation conditions: Non-sin. wave, $V_{\mathrm{C}}=2 \mathrm{~mm} / \mathrm{s}$, $f=0.5 \mathrm{~Hz}, A=3 \mathrm{~mm}$.)

oscillation mark. One is bending type theory ${ }^{14)}$ and the other is overflow type theory. ${ }^{15)}$ Most shapes of oscillation mark were observed as the overflow type in this experiment. Figure 8 shows an example of the distance from solidified shell around meniscus to mold wall, $y_{\mathrm{s}}$, versus time when oscillation mark was formed by overflow type in this 


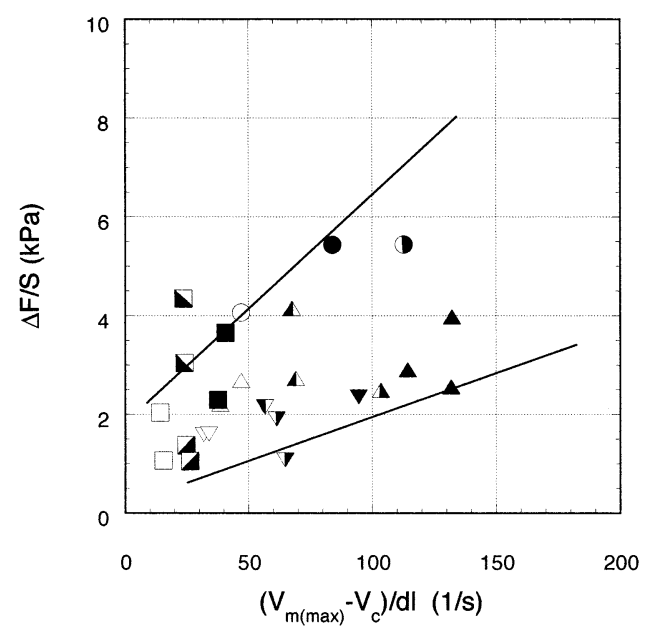

Fig. 9. Relation between friction force, $\Delta F / S$, and the parameter, $\left(V_{\mathrm{m}(\max )}-V_{\mathrm{C}}\right) / d l$ in $t_{\mathrm{p}}$ period. (The correspondence between marks and casting conditions is shown in Table 2.)

time through the observation window. $y_{\mathrm{s}}$ was defined the distance from the central of oscillation mark of which part was far from the mold. The metal surface around meniscus which was contacted with the mold shined brightly and it was assumed that this part was solidified by the watercooled copper mold. It was found that the initial solidified shell began to be apart from the mold about $0.2 \mathrm{~s}$ later after the mold oscillated upwards and time changed from $t_{\mathrm{n}}$ to $t_{\mathrm{p}}$ period. In other casting conditions, the behavior of initial solidified shell was nearly the same, so the distinct effect and difference of casting conditions could not be observed. But the absolute value of distance from mold to solidified shell was larger than normal depth of oscillation mark. The reason was that the observation area was the corner of the strand, where $y_{\mathrm{s}}$ was generally very deep.

\section{Discussions}

\subsection{Friction Force between Mold and Solidified Shell}

If the flow of molten mold powder between mold and solidified shell was assumed to be viscous fluid flow between parallel plates, the friction force between mold and solidified shell can be expressed as follows,

$$
F_{\text {cal. }}=\mu_{\mathrm{v}} \frac{V_{\mathrm{m}}-V_{\mathrm{C}}}{d l}
$$

where $\mu_{\mathrm{v}}$ is viscosity of viscous fluid, $d l$ is thickness of viscous fluid, that is, thickness of mold powder film in this experiment. It was found that friction force increased gradually in the $t_{\mathrm{p}}$ period and decreased rapidly in $t_{\mathrm{n}}$ period from Fig. 2. Figure 9 shows the relation between friction force and the parameter, $\left(V_{\mathrm{m}(\max )}-V_{\mathrm{C}}\right) / d l$ in $t_{\mathrm{p}}$ period.

\subsection{Powder Consumption Rate in $t_{\mathrm{p}}$ and $t_{\mathrm{n}}$ Periods}

It was assumed in the present paper that the movement of fine $\mathrm{Al}_{2} \mathrm{O}_{3}$ tracer represented the behavior of molten mold powder inflow. As the results, it was known that the inflow velocity of mold powder in $t_{\mathrm{p}}$ period was faster than that in $t_{\mathrm{n}}$ period, and the period of inflow of mold powder was observed not only during $t_{\mathrm{p}}$ period but also during $t_{\mathrm{n}}$ period from Fig. 7.

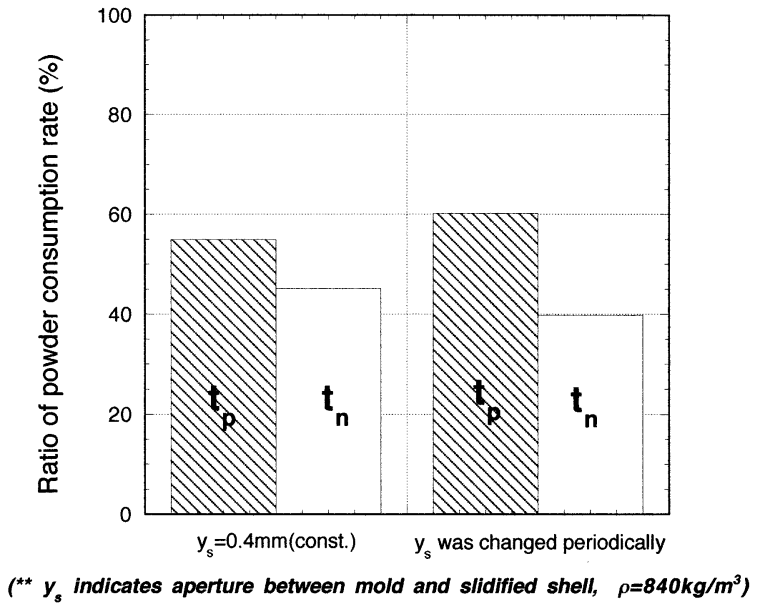

Fig. 10. Comparison of powder consumption rate in $t_{\mathrm{p}}$ and $t_{\mathrm{n}}$ periods.

It was assumed in this paper that the inflow velocity of fine $\mathrm{Al}_{2} \mathrm{O}_{3}$ tracer corresponded with that of molten mold powder in order to calculate the amount of inflow of mold powder. The inflow amount of mold powder was estimated by integrating the inflow velocity of fine $\mathrm{Al}_{2} \mathrm{O}_{3}$ tracer against time and multiplying it by the density of molten mold powder.

$$
q_{t_{\mathrm{p}}}=\rho d_{\mathrm{f}} \int_{t_{\mathrm{p}}} V_{\mathrm{t}}(t) d t, \quad q_{t_{\mathrm{n}}}=\rho d_{\mathrm{f}} \int_{t_{\mathrm{n}}} V_{\mathrm{t}}(t) d t
$$

The ratios of inflow amount, that is, powder consumption rate of mold powder in each period are shown on the left hand side in Fig. 10. The mold powder consumption rate in $t_{\mathrm{p}}$ period was a little larger than that in $t_{\mathrm{n}}$ period.

Generally speaking, the aperture between mold and initial solidified shell was proportional to powder consumption rate from Eq. (5), and it was found from Fig. 8 that it changed periodically in mold oscillation. Therefore, the change of aperture between mold and solidified shell had to be considered when the inflow amount of mold powder was estimated.

$$
q_{t_{\mathrm{p}}}=\rho \int_{t_{\mathrm{p}}} d_{\mathrm{f}}(t) V_{\mathrm{t}}(t) d t, \quad q_{t_{\mathrm{n}}}=\rho \int_{t_{\mathrm{n}}} d_{\mathrm{f}}(t) V_{\mathrm{t}}(t) d t
$$

$d_{\mathrm{f}}(t)$ could be got from observation results like as Fig. 8. The calculation result on the consideration of change of the aperture periodically is shown on the right side in Fig. 10. It was found that the inflow ratio of mold powder in $t_{\mathrm{p}}$ period on consideration of periodical change of aperture was larger than that on the assumption of constant aperture between mold and solidified shell. It was concluded from these estimation that the amount of mold powder consumption in $t_{\mathrm{p}}$ period was more than that in $t_{\mathrm{n}}$ period and was proportional to PSR in mold oscillation.

\subsection{Mechanisms of Inflow of Mold Powder and Formation of Oscillation Mark}

Tada et $a l .{ }^{8)}$ reported in their study using $\mathrm{Pb}-\mathrm{Bi}$ alloy and stearic acid that the deformation, in which initial solidified 


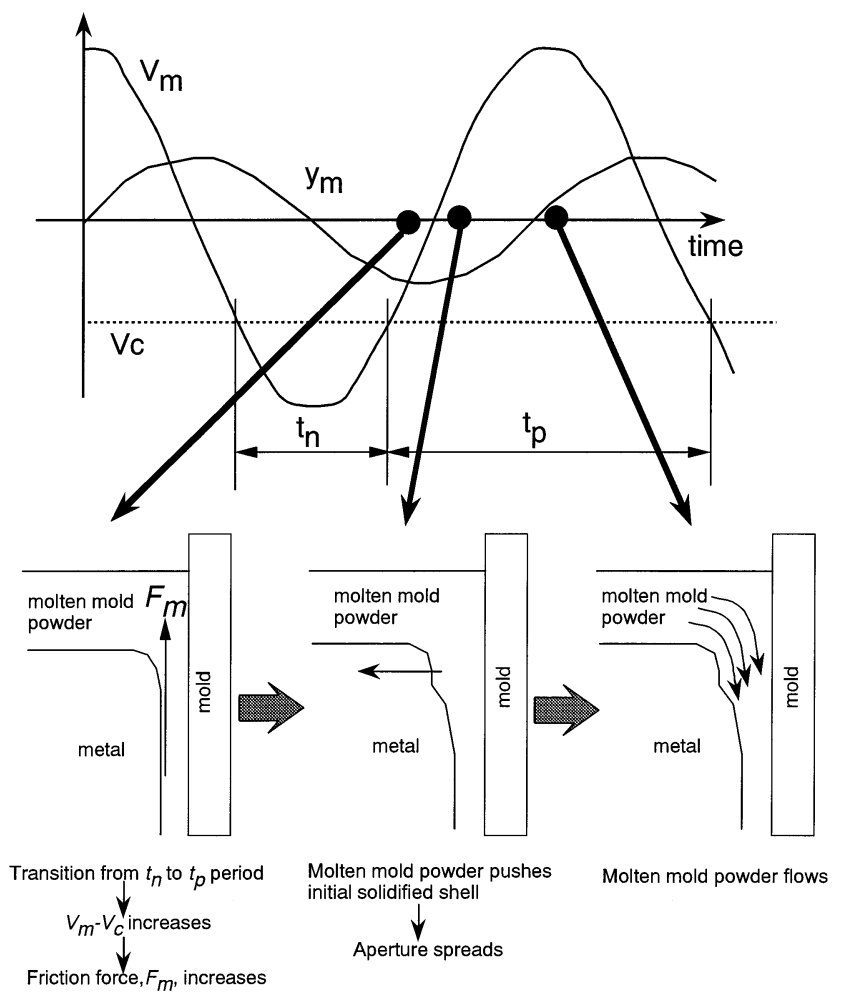

Fig. 11. Schematic diagram of mechanism of behavior of mold powder and initial solidified shell.

shell was bent towards mold, occurred within roughly the first $50 \%$ of $t_{\mathrm{p}}$ period. It was supposed that the oscillation mark formation was caused by the negative pressure of the molten mold powder to initial solidified shell in this period. Itoh et al. ${ }^{10)}$ reported the same observation results in their experiment using $\mathrm{Cu}$ alloy and oxide flux $\left(\mathrm{CaO}-\mathrm{SiO}_{2}-\right.$ $\mathrm{Na}_{2} \mathrm{O}-\mathrm{B}_{2} \mathrm{O}_{3}$ system). Both results were correspondent with our experimental results, but steel and mold powder which were used in continuous casting machine in industrial steel plant were not used in our and their experiments. On the other hand, Itoyama et al. $^{16)}$ reported that the formation of the oscillation mark occurred within $25-50 \% t_{\mathrm{p}}$ period in the case of horizontal oscillation using calculation model. Their experiment was carried out using steel and mold powder, but their horizontal oscillation was special mold oscillation. Strictly speaking, all of our and their experimental and calculation results might not be explained correctly the phenomenon of the formation of oscillation mark of normal mold oscillation in continuous casting machine in steel plant, but all opinions were conducted same conclusions about the period of the formation of oscillation mark. Basically our observation results of the formation of oscillation mark were corresponded with their results.

Furthermore, our new opinion is that the period, in which molten mold powder flowed into the aperture between mold and solidified shell, corresponded to the $t_{\mathrm{p}}$ period, in which the bending back deformation of the initial solidified shell occurred. This was concluded from our observation results that the inflow velocity of molten mold powder into the aperture between mold and solidified shell increased in $t_{\mathrm{p}}$ period.

The mechanism of inflow of mold powder was considered as follows in this experiment where $\mathrm{Sn}-5 \mathrm{mass} \% \mathrm{~Pb}$ and stearic acid were substituted for liquid steel and mold powder. Figure 11 shows schematic diagram of mechanism of behavior of mold powder and initial solidified shell. The friction force begins to increase because $V_{\mathrm{m}}-V_{\mathrm{C}}$ increases gradually after the time changes from $t_{\mathrm{n}}$ to $t_{\mathrm{p}}$ period. And then molten mold powder pushes the initial solidified shell ${ }^{8)}$, and the aperture between mold and solidified shell spreads and the amount of inflow of mold powder increases. Therefore it was concluded in the present work that the $t_{\mathrm{p}}$ period was important period for the both of inflow behavior of mold powder into the aperture between mold and initial solidified shell and also oscillation mark formation.

\section{Conclusions}

The lubrication behavior of mold powder between mold and solidified shell was observed with the experimental apparatus simulated a continuous casting machine using $\mathrm{Sn}-$ $\mathrm{Pb}$ alloy and stearic acid in the present work. The follows were concluded.

(1) The measurement of friction force between mold and solidified shell by load cell set under the mold was useful to know the lubrication behavior of mold powder. The friction force between mold and solidified shell decreased when PSR increased. When the modification rate or amplitude increased and frequency or casting speed decreased, the friction force decreased. These inclinations corresponded with the experience in the industrial continuous casting machine.

(2) Mold powder flowed into the aperture between mold and solidified shell during both $t_{\mathrm{p}}$ and $t_{\mathrm{n}}$ period, and the amount of mold powder consumption in $t_{\mathrm{p}}$ period was more than that in $t_{\mathrm{n}}$ period.

\section{Acknowledgment}

The authors wish to thank Messrs. T. Futatsuka (graduate student at Tohoku University) and H. Yuki (formerly under graduate student at Tohoku University, now River Eletec Corp.) for their assistant and help for the experiment, and also Dr. T. Nagasaka (Tohoku University), Dr. M. Suzuki (Tohoku University, now NKK Corp.), Messrs. I. Sumi and M. Nakada (NKK Corp.) for their useful suggestion and encouragement. This work was financially supported by a Grant-in-Aid for Encouragement for Young Scientists (No. 09750804) from the Ministry of Education, Science, Sports and Culture and the Iron and Steel Institute of Japan which were also gratefully acknowledged.

\section{Nomenclature}

$V_{\mathrm{C}}:$ Casting speed $(\mathrm{mm} / \mathrm{s})$

$f:$ Frequency $(1 / \mathrm{s})$

$A$ : Amplitude ( $\pm \mathrm{mm})$

$\alpha$ : Modification rate ( $\%)$

$y_{\mathrm{m}}:$ Mold displacement $(\mathrm{mm})$

$V_{\mathrm{m}}$ : Mold velocity $(\mathrm{mm} / \mathrm{s})$

$V_{\mathrm{m}(\max )}:$ Maximumu mold velocity in $t_{\mathrm{p}}$ period $(\mathrm{mm} / \mathrm{s})$

$y_{\mathrm{t}}$ : Tracer displacement $(\mathrm{mm})$

$V_{\mathrm{t}}:$ Tracer velocity $(\mathrm{mm} / \mathrm{s})$

$t_{\mathrm{p}}$ : Positive strip time (s)

$t_{\mathrm{n}}$ : Negative strip time (s)

NSR: Negative strip time ratio (\%)

PSR : Positive strip time ratio (\%)

$Q$ : Powder consumption $\left(\mathrm{kg} / \mathrm{m}^{2}\right)$ 
$\rho$ : Density of molten mold powder $\left(\mathrm{kg} / \mathrm{m}^{3}\right)$

$T_{\mathrm{m}}$ : Melting point $(\mathrm{K})$

$\mu_{\mathrm{v}}$ : Viscosity of molten mold powder $(\mathrm{Pa} \cdot \mathrm{S})$

$F_{\mathrm{m}}:$ Load on the mold $(\mathrm{N})$

$F_{1}$ : Load with casting $(\mathrm{N})$

$F_{0}$ : Load without casting $(\mathrm{N})$

$F_{\text {m(max) }}$ : Maximum load on the mold in one period of mold oscillation $(\mathrm{N})$

$F_{\text {m (min) }}$ : Minimum load on the mold in one period of mold oscillation $(\mathrm{N})$

$\Delta F$ : Differnce between maximun and minimum load in one period of mold oscillation $(\mathrm{N})$

$S$ : Contacted area between mold and solidified shell $\left(\mathrm{m}^{2}\right)$

$\Delta F / S$ : Friction force between mold and solidified shell per unit of contacted area $(\mathrm{Pa})$

$F_{\text {cal. }}$ : Calculation value of friction force on the assumption of viscus fluid $(\mathrm{N})$

$d_{\mathrm{f}}$ : Thickness of powder film (mm)

$y_{\mathrm{s}}$ : Aperture between mold and solidified shell ( $\left.\mathrm{mm}\right)$

$q_{t_{\mathrm{p}}}$ : Powder consumption rate during $t_{\mathrm{p}}$ period in one mold oscillation $(\mathrm{kg} / \mathrm{m})$

$q_{t_{\mathrm{n}}}$ : Powder consumption rate during $t_{\mathrm{n}}$ period in one mold oscillation $(\mathrm{kg} / \mathrm{m})$

\section{REFERENCE}

1) T. Kitagawa, H. Mizukami, T. Kawawa and M. Ishiguro: Tetsu-toHagané, 65 (1979), S704.
2) H. Mizukami, K. Kawakami, T. Kitagawa, M. Suzuki, S. Uchida and Y. Komatsu: Tetsu-to-Hagané, 72 (1986), 1862.

3) M. Suzuki, S. Miyahara, T. Kitagawa, S. Uchida, T. Mori and K. Okimoto : Tetsu-to-Hagané, 78 (1992), 113.

4) T. Emi, H. Nakato, Y. Iida, K. Emoto, R. Tachibana, T. Imai and H. Bada: Proceedings of Open Hearth Conference, AIME, 61 (1978), 350 .

5) E. Anzai, T. Ando, T. Shigezumi, M. Ikeda and T. Nakano: SeitetsuKenkyu, 324 (1987), 30.

6) I. Sumi, K. Sasa and S. Asai: Tetsu-to-Hagané, 78 (1992), 447.

7) A. Matsushita, K. Isogami, M. Temma, T. Ninomiya and K. Tsutsumi: Trans. Iron steel Inst. Jpn., 28 (1988), 531.

8) M. Tada, H. Murakami, S. Nishioka, M. Komatsu, T. Ishii and M. Nakada: CAMP-ISIJ, 6 (1993), 1180; M. Tada, H. Murakami, S. Nishioka and M. Komatsu: Initial Stage Solidification of Steel, ISIJ, Tokyo, (1995), 60.

9) M. Kudoh, Y. Itoh, Y. Yonezawa, R. Kikuchi and Y. Horiguchi: CAMP-ISIJ, 10 (1998), 32.

10) Y. Itoh, S. Nabeshima, H. Tozawa, H. Nakato and K. Sorimachi : CAMP-ISIJ, 10 (1997), 183; S. Nabeshima, Y. Itoh, H. Tozawa, H. Nakato and K. Sorimachi: Proceedings of the 4th Decennial International Conference on Solidification Processing, University of Sheffield, Sheffield, (1997), 10.

11) S. Itoyama, M. Washio, H. Nishikawa, H. Yamanaka, S. Tanaka and T. Fujii: Tetsu-to-Hagané, 74 (1988), 1274.

12) K. Nakajima, S. Hiraki, T. Kanazawa and T. Murakami: CAMP-ISIJ, 5 (1992), 1221.

13) T. Kanazawa, S. Hiraki, M. Kawamoto, K. Nakai and K. Hanasaki: Tetsu-to-Hagané, 83 (1997), 701.

14) E. Takeuchi and J. K. Brimacomb: Metall. Trans., 15B (1984), 493.

15) H. Takeuchi, S. Matsumura and Y. Ikehara: Tetsu-to-Hagané, 69 (1983), 1995.

16) S. Itoyama, H. Tozawa, T. Mochida, K. Kurokawa, T. Matsukawa and K. Sorimachi: ISIJ Int., 38 (1998), 461. 